\title{
Badania zjawiska embedment w zabiegach stymulacyjnych
}

\begin{abstract}
W artykule przedstawiono tematykę związaną ze zjawiskiem embedment, czyli wgniataniem ziaren materiału podsadzkowego (ang. proppant) w skałę złożową (ścianę szczeliny). Proces ten ma negatywny wpływ na utrzymanie rozwartości podsadzonej szczeliny po zabiegu hydraulicznego szczelinowania złóż. Opracowano metodykę badania zjawiska embedment oraz zweryfikowano ją analizami laboratoryjnymi przeprowadzonymi na skale łupkowej pochodzącej z polskiego złoża. Do badań zastosowano płyn szczelinujący typu slickwater, dwa rodzaje podsadzek, małą koncentrację powierzchniową podsadzki, dwa różne naprężenia ściskające. Wyniki badań mogą służyć do wstępnej oceny efektywności podsadzenia szczeliny w zabiegach hydraulicznego szczelinowania na etapie ich projektowania.
\end{abstract}

Słowa kluczowe: niekonwencjonalne złoża węglowodorów, hydrauliczne szczelinowanie, proppant, embedment, wgniatanie ziaren podsadzki, rozwartość szczeliny, materiał podsadzkowy, efektywność podsadzenia szczeliny.

\section{Studies of the embedment phenomenon in stimulation treatments}

This paper presents the subject related to the phenomenon of pressing proppant grains in fracture faces (embedment). The phenomenon has a negative impact on maintaining fracture width after hydraulic treatment of reservoirs. A methodology of the studies of the embedment phenomenon was developed and verified by laboratory tests on shale rock from an unconventional Polish reservoir. The laboratory tests used fracturing fluid (slickwater), two different stresses, two different proppants and small surface concentration of proppant. The test results can be used for a preliminary assessment of the efficiency of propped fracture in the hydraulic treatments of reservoirs at the stage of their design.

Key words: unconventional reservoirs, tight gas, formations hydraulic fracturing, proppant, embedment, pressing proppant grains, width fracture, efficiency propped fracture.

\section{Wprowadzenie}

Stosunkowo nową gałęzią przemysłu naftowego jest wydobycie węglowodorów ze złóż niekonwencjonalnych [2, 5, $7,9,11]$. Aby zabiegi stymulacyjne w formacjach niekonwencjonalnych były skuteczne, należy wytworzyć w nich system licznych szczelin, mikropęknięć umożliwiających uwolnienie się zaadsorbowanego gazu oraz przepływ płynów złożowych z sieci porów do odwiertu [2, 5, 7, 9, 11]. Utrzymanie szczeliny w postaci rozwartej po zabiegu hydraulicznego szczelinowania zależne jest miedzy innymi od odporności materiału podsadzkowego na naprężenia ściskające oraz odporności skały na zjawisko wciskania ziaren podsadzki w ściany szczeliny, z ang. embedment [1, 2, 4-11]. W sylursko-ordowickich skałach łupkowych występujących we wschodniej części Polski podstawowym składnikiem budującym matrycę skalną są minerały nieilaste - głównie kwarc $(60 \div 70 \%)$, z dużą zawartością minerałów ilastych - przede wszystkim illitu $(30 \div 40 \%)[5,7]$. W przypadku obecności minerałów ilastych (powyżej 40\%) skała łupkowa charakteryzuje się wysokim stopniem plastyczności, a tym samym jest podatna na wgniatanie ziaren podsadzki w ścianę szczeliny po zabiegach stymulacyjnych $[5,7]$. Do szczelinowania złóż niekonwencjonalnych stosuje się: technologię slickwater, żele polimerowe, sieciowane żele polimerowe, płyny na bazie środków powierzchniowo czynnych, piany, ciekły dwutlenek węgla $[1,2,6]$. Rodzaj płynów szczelinujących wpływa na wielkość zjawiska embedment. 


\section{Wpływ zjawiska embedment na rozwartość szczeliny wypełnionej podsadzką}

Oprócz sposobu transportu i umieszczania materiału podsadzkowego w wytworzonej szczelinie na efektywność jej podsadzenia oraz uzyskanie odpowiedniej przewodności wpływa między innymi podatność skały złożowej na wgniatanie ziaren podsadzki w ścianę szczeliny, tzw. embedment $[1,5,7-9]$. Zjawisko to powoduje spadek rozwartości szczeliny $W_{f}$, a tym samym przyczynia się do spadku przewodności szczeliny wypełnionej podsadzką $[4,5,7,8,9,12,14]$ (rysunek 1). Ma ono miejsce podczas zamykania się wytworzonej szczeliny podczas zabiegu hydraulicznego szczelinowania.

Literatura $[1,3,5,7,10,11]$ podaje, że na wielkość zjawiska embedment wpływa między innymi: rodzaj skały (skład mineralogiczny), właściwości mechaniczne skały złożowej (moduł Younga, współczynnik Poisson’a), rodzaj materiału podsadzkowego, wielkości naprężeń ściskających w złożu, czas oddziaływania naprężeń ściskają-

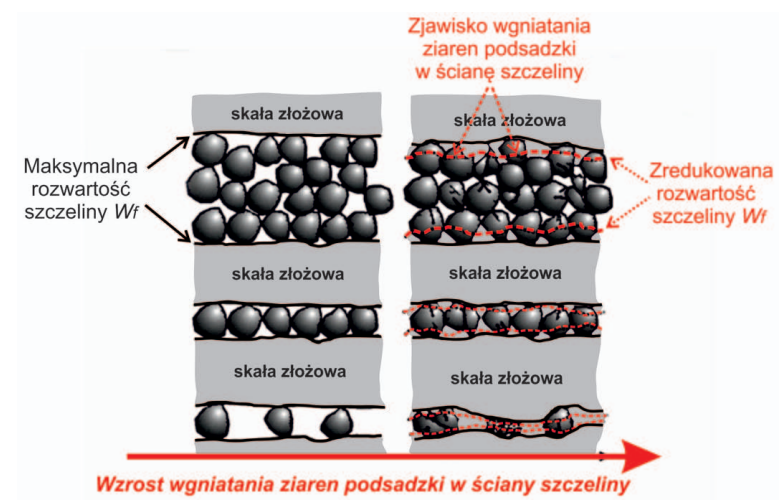

Rys. 1. Wpływ zjawiska embedment na efektywne utrzymanie rozwartości szczeliny wypełnionej podsadzką po zabiegu hydraulicznego szczelinowania $[4,5,7,12]$

cych, rodzaj płynów szczelinujących i złożowych, technologia eksploatacji złoża.

\section{Metodyka badania zjawiska embedment}

Do badań wykorzystano metodykę opracowaną w INiG - PIB [5, 7, 8]. Chropowatość wyznacza się pod mikroskopem stereoskopowym (rysunek 3c), umożliwiającym cyfrowe obrazowanie oraz analizę chropowatości powierzchni szczeliny. Dla kilku wytypowanych obszarów na powierzchni ściany szczeliny wykonuje się cyfrowy obraz, a następnie dla każdego z nich wyznacza się średnią chropowatość z kilku profili chropowatości wzdłuż wytypowanych odcinków pomiarowych. Metodę wyznaczenia chropowatości powierzchni wzdłuż danego odcinka pomiarowego przedstawiono na rysunku $2[5,7,9]$ oraz przy pomocy równania $1[5,7-9]$.

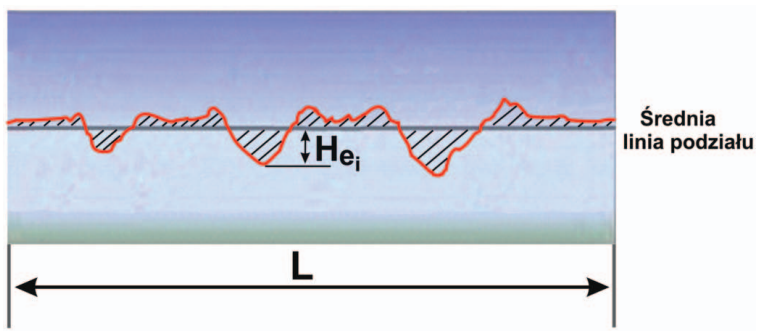

Rys. 2. Przykładowy profil chropowatości powierzchni wzdłuż odcinka pomiarowego dla wytypowanego obszaru na powierzchni czołowej ściany szczeliny $[5,7,9]$

$$
R=\frac{\sum_{i=0}^{n} H_{p_{i}}+\sum_{i=0}^{n} H_{v_{i}}}{n_{p}+n_{v}}
$$

gdzie:

$R$ - chropowatość profilu powierzchni wzdłuż odcinka pomiarowego $[\mathrm{mm}]$,
$H_{p}$ - wysokość szczytu [mm],

$H_{v}$ - głębokość doliny [mm],

$n_{p}$ - liczba wszystkich szczytów [-],

$n_{v}$ - liczba wszystkich dolin [-].

Średnią chropowatość $R_{s r}$ dla całej powierzchni ściany szczeliny określa się jako średnią arytmetyczną z chropowatości profili wyznaczonych dla poszczególnych wytypowanych obszarów.

Następnie podsadzkę umieszcza się pomiędzy dwoma cylindrycznymi rdzeniami skalnymi w komorze pomiarowej (rysunek 3b) $[5,7,8]$, poddając ją działaniu naprężenia ściskającego przez zadany odcinek czasu. Po upływie tego okresu rozbiera się komorę i analizuje powierzchnie rdzeni pod mikroskopem stereoskopowym (rysunek 3c) [5, 7, 8], umożliwiającym ich cyfrowe obrazowanie oraz analizę.

Analiza powierzchni rdzenia polega na określeniu średniej głębokości wgnieceń ziaren podsadzki w ścianę szczeliny. Metodę wyznaczenia głębokości wgnieceń ziaren (dolin) w powierzchnię szczeliny wzdłuż odcinka pomiarowego przedstawiono na rysunku 4 oraz przy pomocy równania $2[5,7,8]$.

$$
H_{e}=\frac{\sum_{i=0}^{n} H_{e_{i}}}{n_{e}}
$$

gdzie:

$H_{e}$ - średnia głębokość wgnieceń ziaren podsadzki w ścianę szczeliny dla profilu, wzdłuż odcinka pomiarowego [mm], 


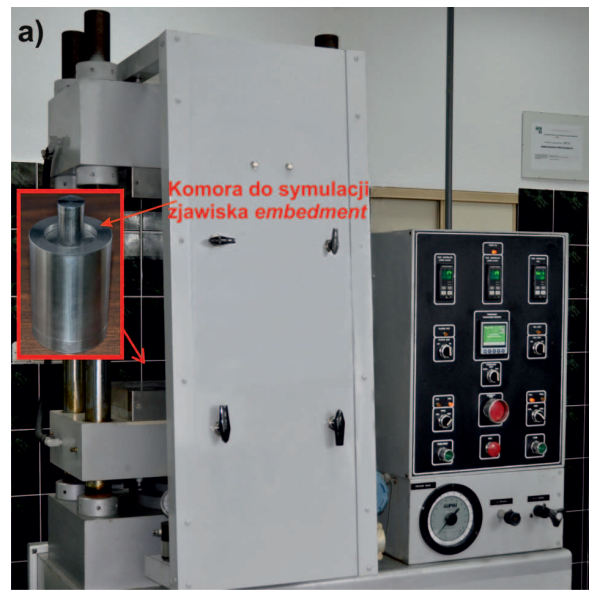

b)
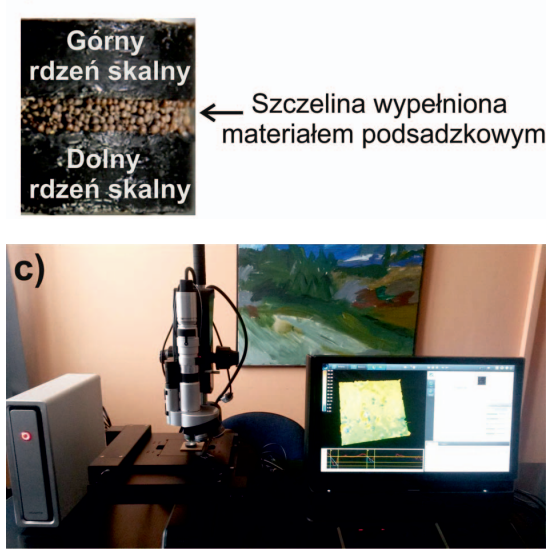

Rys. 3. Stanowisko badawcze: a) prasa hydrauliczna wraz z komorą do symulacji zjawiska embedment w INiG - PIB; b) schemat umieszczenia materiału podsadzkowego w szczelinie;

c) mikroskop stereoskopowy wraz z oprogramowaniem $[5,7]$
$H_{e i}-$ głębokość doliny [mm],

$n_{e}-$ liczba wszystkich dolin [-].

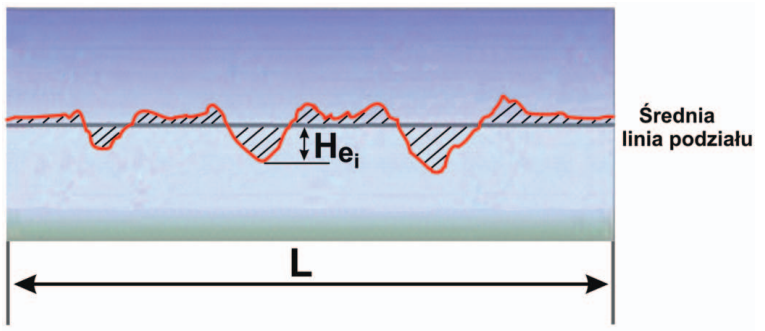

Rys. 4. Przykładowy profil głębokości wgnieceń ziaren (dolin) wzdłuż odcinka pomiarowego dla wytypowanego obszaru na powierzchni ściany szczeliny $[5,7]$
Całkowitą średnią głębokość $H e_{c}$ wgnieceń ziaren podsadzki w ściany szczeliny [mm] określa się według równania $3[5,7,8]$ :

$$
H_{e_{c}}=H_{e_{s r} r g}+H_{w_{s r d}}
$$

gdzie:

$H_{e_{s r} g}$ - średnia głębokość wgnieceń ziaren podsadzki w górną ścianę szczeliny, będąca średnią arytmetyczną uzyskanych wartości dla poszczególnych wytypowanych obszarów [mm],

$H_{e_{s}^{s} r d}$ - średnia głębokość wgnieceń ziaren podsadzki w dolną ścianę szczeliny, będąca średnią arytmetyczną uzyskanych wartości dla poszczególnych wytypowanych obszarów [mm].

\section{Badania laboratoryjne zjawiska embedment}

Do badań wykorzystano skałę typu łupkowego, pochodzącą z polskiego złoża. Posiadała ona w swoim składzie mineralogicznym między innymi: 24,4\% kwarcu, 14,2\% węglanów, 47,7\% minerałów ilastych oraz $13,7 \%$ pozostałych minerałów [5, 7]. Znaczną ilość zabiegów w skałach łupkowych przeprowadza się z użyciem cieczy nieagresywnej o niskiej lepkości, tzw. technologia slickwater. Płyn szczelinujący użyty do badań składał się z następujących substancji: woda wodociągowa, biocyd, środek (stabilizator) zapobiegający pęcznieniu minerałów ilastych i łupkowych, mikroemulsja, środek ograniczający opory przepływu (poliakryloamid). Do podsadzenia szczeliny została wykorzystana podsadzka kwarcowa 40/70 oraz lekka podsadzka ceramiczna 40/70. Rozmiar ich ziaren wynosił 0,425 $\div 0,212 \mathrm{~mm}$

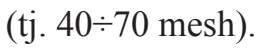

W pierwszej kolejności wyznaczono średnią pierwotną chropowatość dla całej powierzchni czołowej rdzenia (ściany szczeliny). Wynosiła ona $0,00047 \mathrm{~mm}( \pm 0,00006 \mathrm{~mm})[5,7]$. Następnie wykonano laboratoryjną symulację zjawiska wgniatania ziaren podsadzki w ściany szczeliny dla podsadzki kwarcowej (test nr 1) oraz dla lekkiej podsadzki ceramicznej (test nr 2). Badania wykonano na prasie hydraulicznej (rysunek 3a), według uprzednio przedstawionej metodyki badawczej. Cylindryczne rdzenie skalne były wcześniej nasycane płynem szczelinującym przez okres 24 godzin w temperaturze pokojowej. Całkowitą średnią głębokość wgnieceń ziaren podsadzki w ściany szczeliny wyznaczano z czterech odcinków pomiarowych dla dwóch obszarów, wytypowanych na powierzchni czołowej górnego i dolnego rdzenia dla testu nr 1 (rysunki 5a, b, c, d) oraz dla testu nr 2 (rysunki 6a, b, c, d). Dodatkowo wykonano badania maksymalnej, możliwej do uzyskania, rozwartości podsadzonej szczeliny. W badaniach tych podsadzka była umieszczana pomiędzy dwiema cylindrycznymi kształtkami stalowymi o twardości 48HRC (dla wykluczenia zjawiska embedment) w warunkach odpowiadającym testom nr 3 i 4. Badania przeprowadzono na prasie hydraulicznej dodatkowo wyposażonej w szczelinościomierz LVDT. Warunki wykonania testów zostały przedstawione w tablicy 1.

Niepewność oszacowanej rozwartości szczeliny wypełnionej materiałem podsadzkowym, wyznaczona na podstawie dokładności szczelinościomierza LVDT, wynosiła 0,001 mm. 


\section{NAFTA-GAZ}

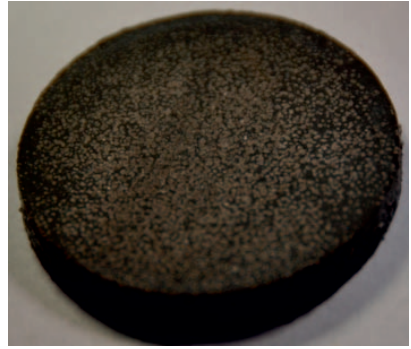

Powierzchnia czołowa górnego rdzenia

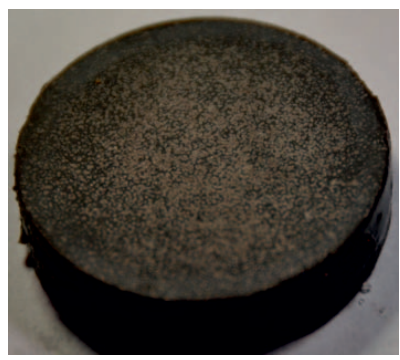

Powierzchnia czołowa dolnego rdzenia

C)

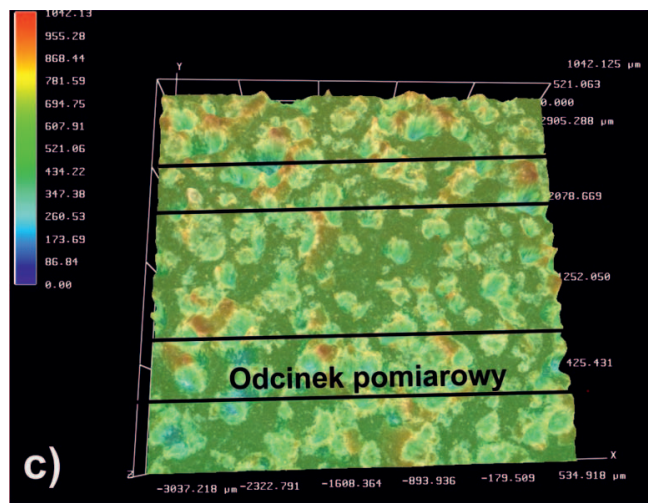

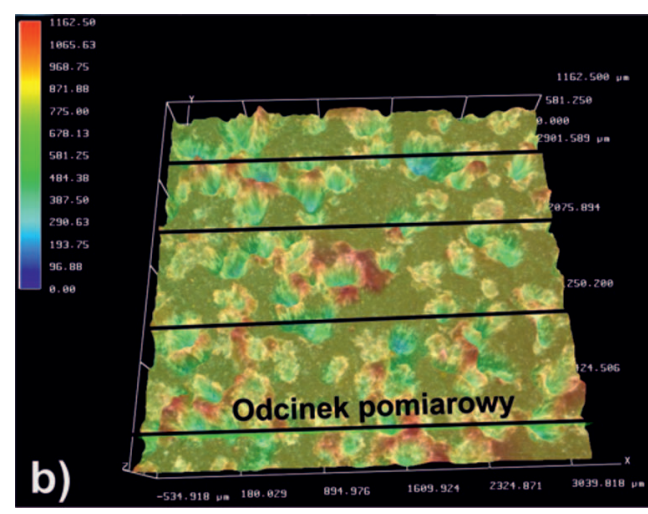

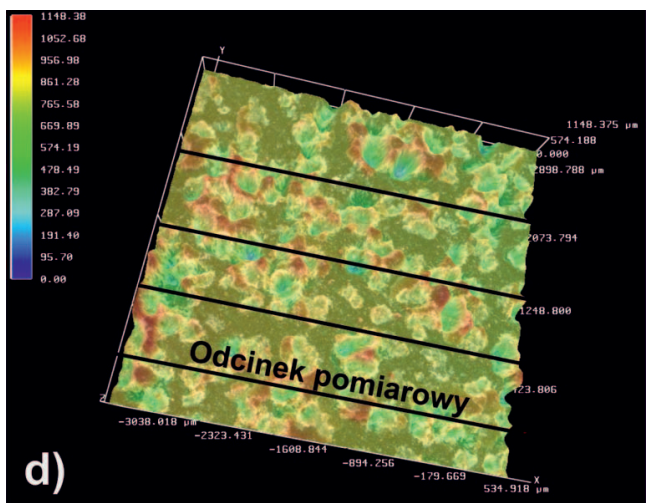

Rys. 5. Określenie średniej głębokości wgnieceń ziaren podsadzki w ściany szczeliny, test nr 1, dla górnego rdzenia: a) obszar nr 1, b) obszar nr 2; dla dolnego rdzenia: c) obszar nr 1, d) obszar nr $2[5,7]$

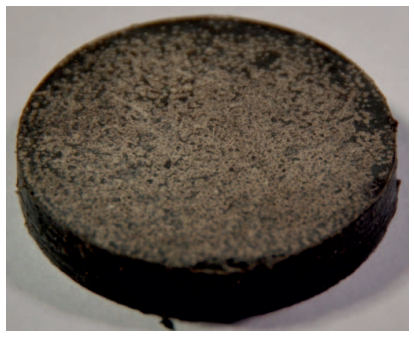

Powierzchnia czołowa górnego rdzenia
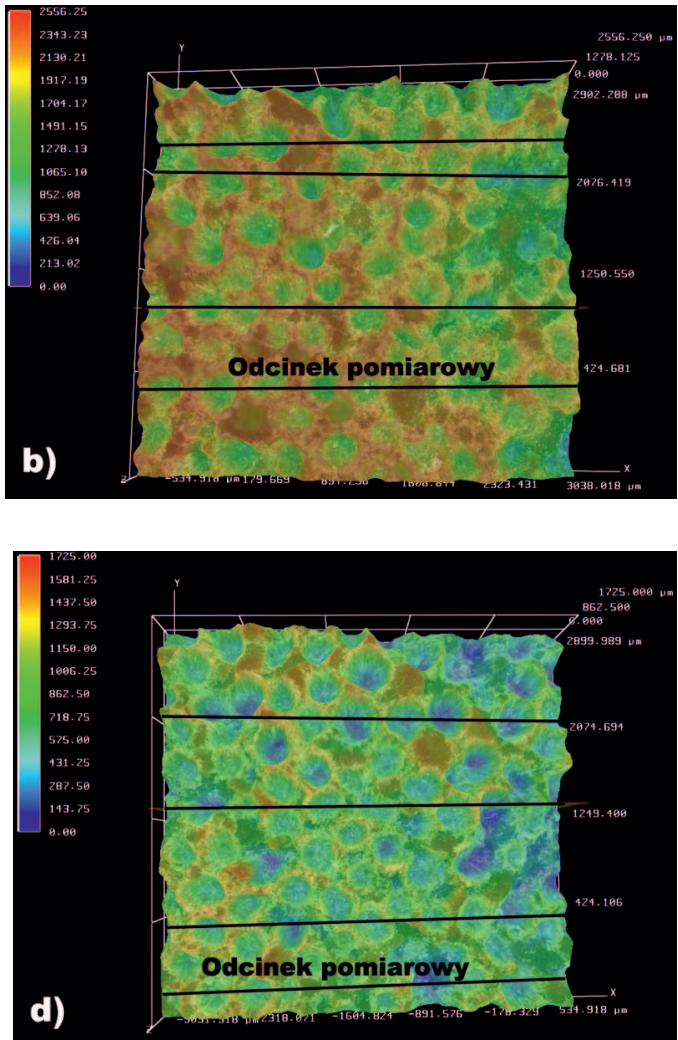

b)

d)

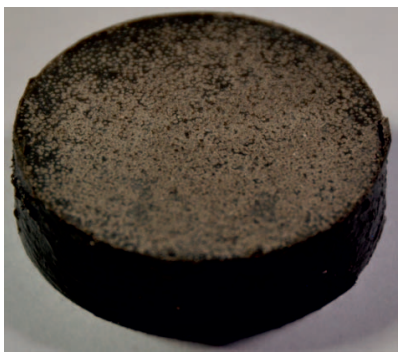

Powierzchnia czołowa dolnego rdzenia
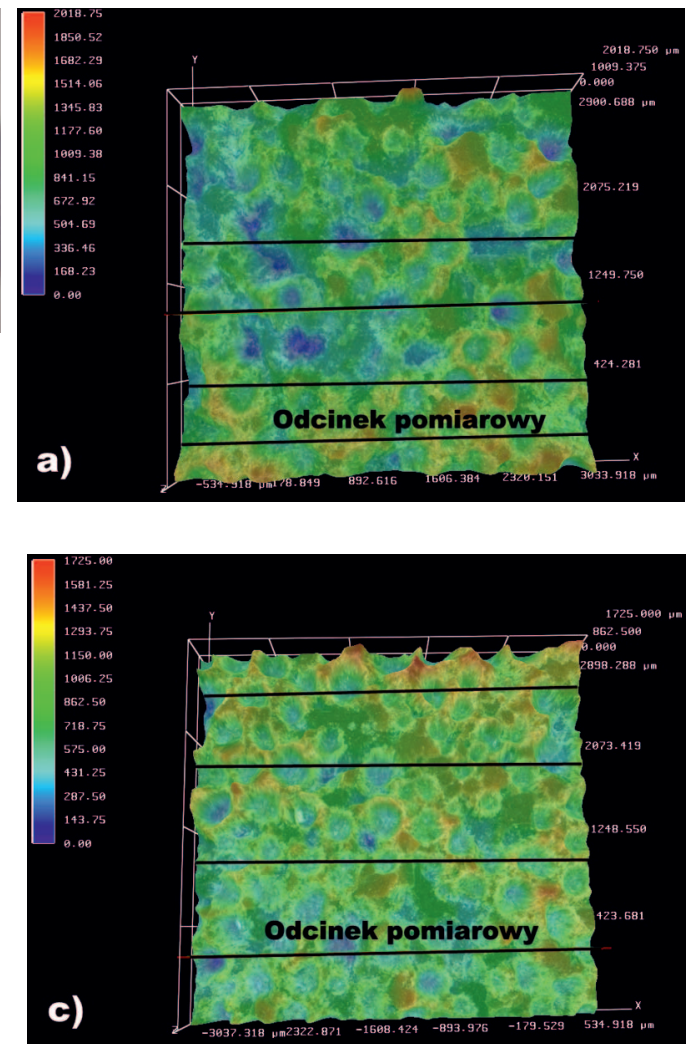

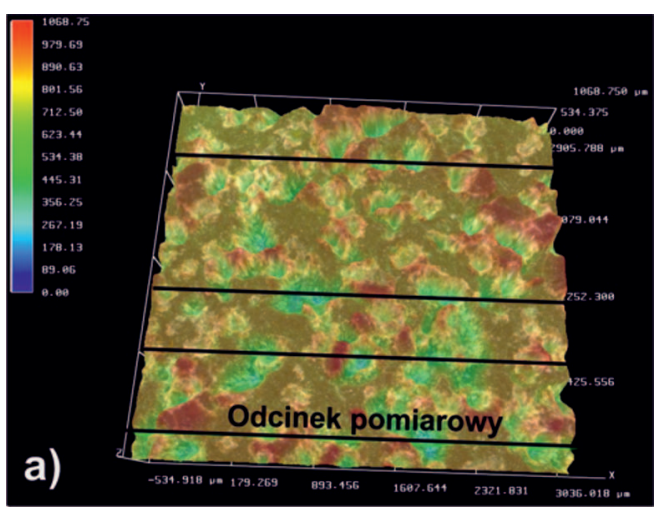

Rys. 6. Określenie średniej głębokości wgnieceń ziaren podsadzki w ściany szczeliny, test nr 2, dla górnego rdzenia: a) obszar nr 1, b) obszar nr 2; dla dolnego rdzenia: c) obszar nr 1, d) obszar nr 2 [7] 
Niepewność oszacowanej całkowitej średniej głębokości wciskania ziaren materiału podsadzkowego w ściany szczeliny (skałę), wyznaczona na podstawie odchylenia standardowego od wartości średniej, nie przekraczała 0,042 mm.

Dla określenia wpływu zjawiska embedment na efektywność podsadzenia szczeliny po zabiegu hydraulicznego szczelinowania złoża wyznaczono rozwartość szczeliny $W_{f}$ wypełnionej materiałem podsadzkowym [mm], według równania 4, oraz procentowy spadek rozwartości szczeliny $P S W_{f}$ wypełnionej podsadzką z uwzględnieniem zjawiska embedment $[\%]$, na podstawie równania 5 .

$$
W_{f}=W_{f m}-H_{e_{c}}
$$

gdzie: $W_{f m}$ - maksymalna możliwa do uzyskania rozwartość szczeliny wypełnionej materiałem podsadzkowym, bez występowania zjawiska embedment [mm].
Tablica 1. Warunki wykonania testów

\begin{tabular}{|l|c|}
\hline Temperatura testu $\left[{ }^{\circ} \mathrm{C}\right]$ & 28,0 \\
\hline $\begin{array}{l}\text { Koncentracja powierzchniowa podsadzki } \\
{\left[\mathrm{kg} / \mathrm{m}^{2}\left(\mathrm{lb} / \mathrm{ft}^{2}\right)\right]}\end{array}$ & $0,98(0,2)$ \\
\hline $\begin{array}{l}\text { Czas działania zadanego naprężenia } \\
\text { ściskającego [godz.] }\end{array}$ & 6 \\
\hline Dla podsadzki kwarcowej 40/70 - Testy nr 1 i nr 3 \\
\hline Zadane naprężenie ściskające $[\mathrm{MPa}(\mathrm{psi})]$ & $41,4(6000)$ \\
\hline Dla lekkiej podsadzki ceramicznej 40/70 - Testy nr 2 i nr 4 \\
\hline Zadane naprężenie ściskające $[\mathrm{MPa}(\mathrm{psi})]$ & $68,9(10000)$ \\
\hline
\end{tabular}

$$
P S W_{f}=\frac{H_{e_{c}}}{W_{f_{m}}} \cdot 100
$$

Wyniki badań przedstawiono na rysunku 7.

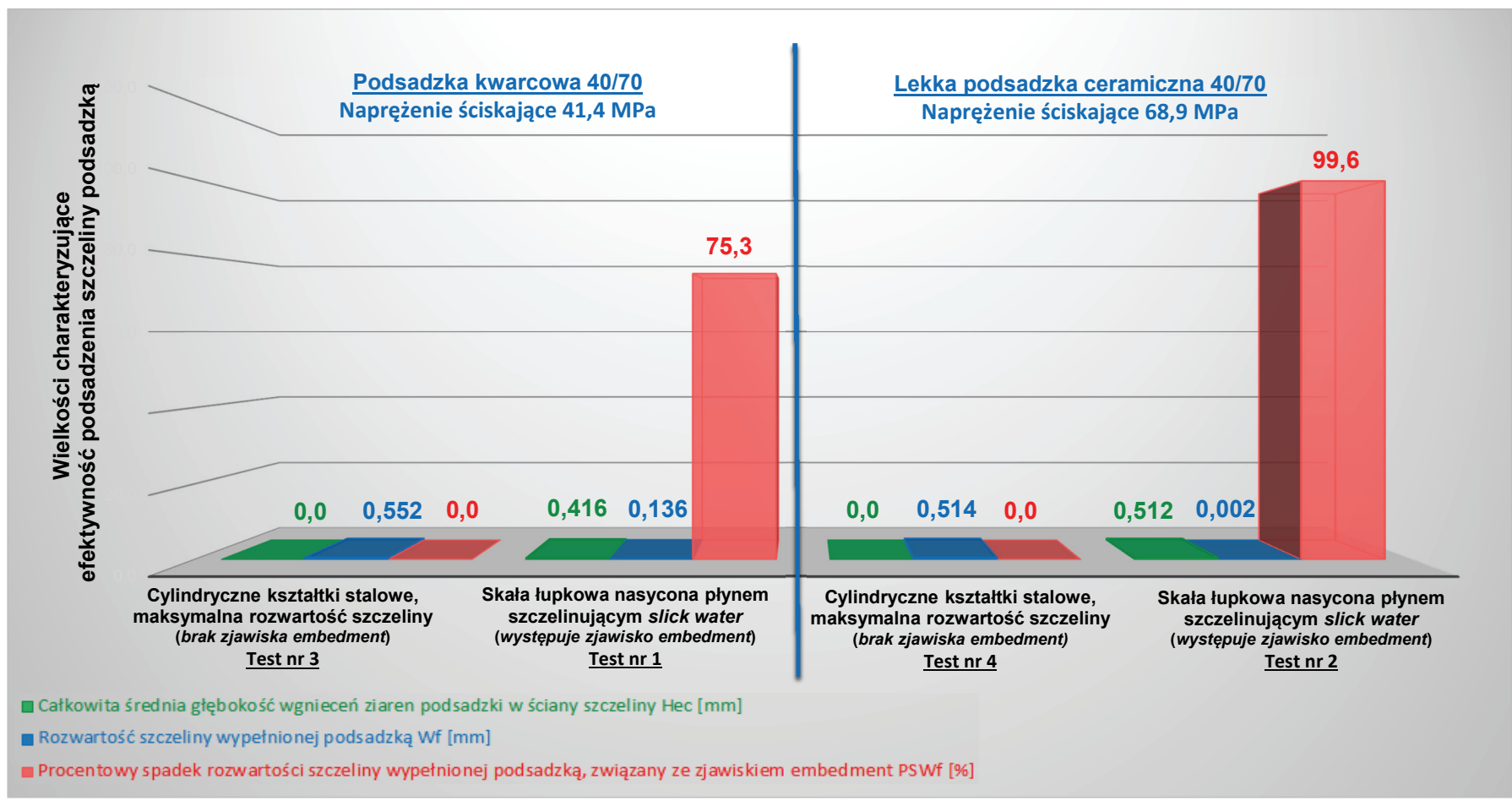

Rys. 7. Wpływ zjawiska embedment na efektywność podsadzenia szczeliny podsadzką kwarcową 40/70 oraz ceramiczną 40/70 o koncentracji powierzchniowej $0,98 \mathrm{~kg} / \mathrm{m}^{2}$, po zabiegu hydraulicznego szczelinowania

\section{Podsumowanie}

Dla szczeliny wypełnionej podsadzką kwarcową 40/70, znajdującą się pomiędzy nasyconymi płynem szczelinującym rdzeniami ze skały łupkowej (w warunkach testu nr 1), uzyskano całkowitą średnią głębokość $H_{e c}$ wgnieceń ziaren podsadzki w ściany szczeliny rzędu $0,416 \mathrm{~mm}$. Zjawisko embedment spowodowało spadek rozwartości szczeliny o 75,3\% w stosunku do jej maksymalnej rozwartości 0,552 mm (bez zjawiska embedment), możliwej do otrzymania w warunkach testu nr 3. Natomiast dla nasyconych płynem szczelinującym rdzeni ze skały łupkowej i szczeliny wypełnionej lekką podsadzką ceramiczną 40/70 (w warunkach testu nr 2) uzyskano $H_{e c}$ rzędu 0,512 mm. Zwiększenie naprężenia ściskającego do wartości 68,9 MPa spowodowało wzrost zjawiska wgniatania ziaren podsadzki w skałę łupkową do wartości $0,512 \mathrm{~mm}$. W związku z tym maksymalna rozwartość podsadzonej szczeliny, wynosząca $0,514 \mathrm{~mm}$ (bez zjawiska embedment) w warunkach testu nr 4, zmniejszyła się o 99,6\%. W oparciu o uzyskane wy- 
niki można wnioskować, że nasycona płynem szczelinującym badana skała łupkowa charakteryzuje się podwyższoną plastycznością, małą efektywnością podsadzenia szczeliny oraz słabą odpornością na zjawisko embedment. Tym samym przy wyższych naprężeniach ściskających dochodzi do całkowitego zamknięcia się szczeliny wypełnionej podsadzką, w szczególności dla niskiej koncentracji powierzchniowej podsadzki rzędu $0,98 \mathrm{~kg} / \mathrm{m}^{2}\left(\mathrm{tj} .0,2 \mathrm{lb} / \mathrm{ft}^{2}\right)$.

Prosimy cytować jako: Nafta-Gaz 2016, nr 12, s. 1101-1106, DOI: 10.18668/NG.2016.12.13

Artykuł nadesłano do Redakcji 18.10.2016 r. Zatwierdzono do druku 24.11.2016 r.

Artykuł powstał na podstawie pracy statutowej pt. Badania zjawiska wciskania ziaren materiału podsadzkowego w ściany szczeliny po zabiegu szczelinowania - praca INiG - PIB na zlecenie MNiSW; nr zlecenia: 0020/KS/14, nr archiwalny: DK-4100-20/14.

\section{Literatura}

[1] Alramahi B., Sundberg M.I.: Proppant embedment and conductivity of hydraulic fractures in shales. American Rock Mechanics Association, 46th U.S. Rock Mechanics/Geomechanics Symposium, 24-27.06.2012, Chicago, Illinois. ARMA 12-291.

[2] Czupski M., Kasza P., Wilk K.: Ptyny do szczelinowania złóż niekonwencjonalnych. Nafta-Gaz 2013, nr 1, s. 42-50.

[3] Ghassemi A., Suarez-Rivera R.: Sustaining fracture area and conductivity of gas shale reservoirs for enhancing longterm production and recovery. Projekt nr 08122-48, RPSEA, 15.05.2012.

[4] Legarth B., Huenges E., Zimmermann G.: Hydraulic fracturing in a sedimentary geothermal reservoir: Results and implications. International Journal of Rock Mechanics \& Mining Sciences 2005, vol. 42, s. 1028-1041.

[5] Masłowski M.: Badania zjawiska wciskania ziaren materiatu podsadzkowego w ściany szczeliny po zabiegu hydraulicznego szczelinowania złóż niekonwencjonalnych. Nafta-Gaz 2015, nr 7, s. 461-471.

[6] Masłowski M.: Materiały podsadzkowe do zabiegów hydraulicznego szczelinowania złóż niekonwencjonalnych. Nafta-Gaz 2014, nr 2, s. 1-86.

[7] Masłowski M. i zespół: Badania zjawiska wciskania ziaren materiału podsadzkowego $w$ ściany szczeliny po zabiegu szczelinowania. Praca statutowa Instytutu Nafty i Gazy - PIB, Krosno, październik 2014, nr zlecenia 20/KS/14, nr archiwalny: DK-4100-20/147, s. 1-78.

[8] Masłowski M. i zespół: Sposób wyznaczania zmniejszenia wysokości podsadzonej szczeliny. Zgłoszenie patentowe nr P.412971, 30.06.2015.

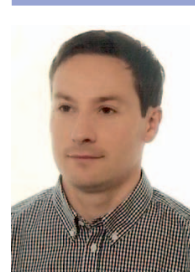

Mgr inż. Mateusz MASŁOWSKI

Asystent w Zakładzie Stymulacji Wydobycia

Węglowodorów.

Instytut Nafty i Gazu - Państwowy Instytut Badawczy

ul. Lubicz 25 A

31-503 Kraków

E-mail: mateusz.maslowski@inig.pl
[9] Morales H.: Sustaining fracture area and conductivity of gas shale reservoirs for enhancing long-term production and recovery. RPSEA Unconventional Gas Conference 2012: Geology, the Environment, Hydraulic Fracturing, Canonsburg 17-18.04.2012.

[10] Reinicke A., Legarth B., Zimmermann G., Huenges E., Dresenn G.: Hydraulic fracturing and formation damage in a sedimentary geothermal reservoir. ENGINE - Enhanced Geothermal Innovative Network for Europe Workshop 3, "Stimulation of reservoir and microseismicity" Kartause Ittingen, Zürich, 29.04-1.07.2006.

[11] Reinicke A., Rybacki E., Stanchits S., Huenges E., Dresen G.: Hydraulic fracturing stimulation techniques and formation damage mechanisms - Implications from laboratory testing of tight sandstone - proppant systems. Chemie dee Erde 2010, vol. 70, s. 107-117.

[12] Sato K., Ichikawa M.: Post-Frac analysis indicating multiple fractures created in a volcanic formation. SPE 39513, Proceedings SPE India oil and gas conference and exhibition, New Delhi 1998, s. 1-10.

[13] Suarez-Rivera R., Behrmann L., Burghardt J., Stanchits S., Edelman E., Surdi A.: Defining three regions of hydraulic fracture connectivity in unconventional reservoirs, help designing completions with improved long-term productivity. SPE 166505, 2013

[14] Volk L.J., Raible C.J., Carrol H.B., Spears J.S.: Embedment of high strength proppant into low-permeability reservoir rock. SPE/DOE 9867, 1981.

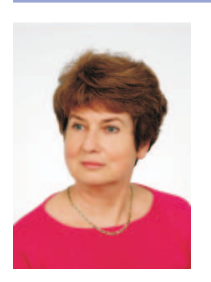

Mgr inż. Elżbieta BIAŁY

Starszy specjalista badawczo-techniczny w Zakładzie Stymulacji Wydobycia Węglowodorów. Instytut Nafty i Gazu - Państwowy Instytut Badawczy ul. Lubicz 25 A

31-503 Kraków

E-mail: elzbieta.bialy@inig.pl 